Acta Horticulturae et Regiotecturae 2

Nitra, Slovaca Universitas Agriculturae Nitriae, 2015, pp. 45-48

\title{
STOMATAL DENSITY IN MISCANTHUS LEAVES
}

\author{
Žaneta PAUKOVÁ, ${ }^{*}$ Zuzana JUREKOVÁ
}

Slovak University of Agriculture in Nitra, Slovak Republic

\begin{abstract}
In this study, the number of stomata per unit area was determined in the perennial energy grass of two genotypes Miscanthus $x$ giganteus (Greef et Deuter) and M. sinensis 'Tatai' on arable land in the South-western Slovakia. The dynamics of stomatal density per $\mathrm{mm}^{2}$ was determined by non-destructive method in three randomly selected clumps. The number of stomata per $\mathrm{mm}^{2}$ of area varied from $125 \pm 23$ to $327 \pm 47$, stomatal length ranged from $33.9 \pm 4.7 \mu \mathrm{m}$ to $35.3 \pm 3.4 \mu \mathrm{m}$, and stomatal width ranged from $17.5 \pm 2.3 \mu \mathrm{m}$ to $18.8 \pm 2.8 \mu \mathrm{m}$ in the two genotypes. We confirmed ontogenetic heterogeneity of leaf area size and stomatal size parameters.
\end{abstract}

Keywords: energy plant, Miscanthus, stomata, stomatal density, cardinal points

The perennial grass Miscanthus with C4 mechanism of photosynthesis is considered a suitable energy crop for cultivation in climatic conditions of Europe due to its strong growth, great productive potential and adaptability to environmental conditions.

The potential ability of the crop stand to form biomass depends largely on leaf area, anatomical, morphological and functional characteristics of leaves. Space that leaves occupy in the stand is determined by genotype and environmental conditions that allow bigger or smaller expansion of the leaf area (Volkenburgh, 1999). Stomatal density, as well as their size and the size of stomatal slit are considered to be relatively plastic features (Richardson et al., 2001) that are potentially adaptive to environmental changes. It was confirmed that stomatal density depends on the soil water content (Xu and Zhou, 2008), light (Thomas et al., 2003) and $\mathrm{CO}_{2}$ concentration in air (Woodward, Kelly, 1995).

The aim of our study was to evaluate the density and localization of stomata in leaves of two genotypes of Miscanthus sinensis grown in field conditions on arable land. The stomata were studied on both sides of the leaf skin, depending on their ontogeny, position and size of the leaf area.

\section{Material and methods}

The research was carried out at the field trial base belonging to the University Farm Holding of the Slovak University of Agriculture in Kolínany. The research plot is located $13 \mathrm{~km}$ from Nitra ( $\left.48^{\circ} 21^{\prime} 20^{\prime \prime} \mathrm{N}, 18^{\circ} 12^{\prime} 23^{\prime \prime} \mathrm{E}\right)$. It belongs to the cadastral area of Kolínany. The code of the soil quality defined by BSEU is 0111002 . The main soil type is gley fluvisol, in terms of grain structure it belongs to moderately heavy soils. In terms of exposure, the area is plain without an expression of surface erosion $\left(0^{\circ}\right.$ to $\left.1^{\circ}\right)$. Soils are deep $(60 \mathrm{~cm}$ or more) and without skeleton.

The two genotypes used in the research were Miscanthus $\times$ giganteus and Miscanthus sinensis 'Tatai'. M. $\times$ giganteus Greef et Deu is a vital triploid hybrid (57chromosomes) (Greef et Deuter, 1993). The planting material consisted of rhizomes provided by the company Hannes Stelzhammer, Austria. M. sinensis 'Tatai' is also a triploid hybrid (57 chromosomes). It was bred by crosspollination of Miscanthus sinensis genotypes. The planting material consisted of seedlings grown in vitro in the Power-H Kft, Hungary. Before planting, the seedlings were planted individually in rooting containers with a soil substrate (Jureková et al., 2012, 2013; Prčík a Kotrla, 2013).

The leaf area size $A\left(\mathrm{~mm}^{2}\right)$ was determined by the nondestructive method (Clifton-Brown, Lewandowski, 2000) directly in the field conditions. The dynamics of stomatal density per $\mathrm{mm}^{-2}$ in the leaves was determined by the non-destructive method in three selected clumps for each genotype in 2013. The analysis was performed on designated stem on juvenile, adult and senescent leaves located in the middle of a stand (approximately fifth leaf from the bottom), exposed to northern, southern, eastern and western direction by the micro-relief method (Pazourek, 1963). The samples were collected in the middle part of leaves outside the main vein on the adaxial (top) and abaxial (bottom) skin surface in May, June and July, 2013. The evaluation of the preparations was carried out by the optical microscope Axiostar plus, Carl Zeiss lens, CP-Achromat $40 \times /$ 0.65, $10 \times$ eyepiece PI / 18, Canon Utilities software Zoom Browser EX 4.6 and hardware Acer Travel Mate 4600, Canon Power Shot A 95. Totally, 144 microscopic view-fields were considered in the counting. Stomata length and width were measured in 88 randomly selected stomata. Statistical significance of the 
differences was evaluated by the LSDtest in the Statgraphic Plus software.

\section{Results and discussion}

In stands, plant leaves adapt their growth to environmental conditions and thus affect the functional properties and characteristics of the whole plant. The leaves grow during their individual ontogeny, maturity and age according to the position on stems. Basal (oldest) leaves wither already during July. The leaves of the studied Miscanthus genotypes grew differently (Table 1) and differed also in the growth of the leaf area according to the cardinal directions. Young leaves of $M . \times$ giganteus created in juvenile growth stage larger area in the northern orientation, the leaves of $M$. sinensis 'Tatai' created larger area in the eastern orientation. The leaves oriented to the north did not grow in the maturity stage, unlike the leaves with the eastern orientation. The leaf area size of senescent leaves of the both genotypes decreased regardless of the position in relation to the cardinal directions. The leaves gradually dried up and withered.

During the research in 2013, we confirmed statistically highly significant dependence of the number of stomata on genotype in the skin of juvenile leaves $\left(\mathrm{LSD}_{0.05}\right.$ test \pm 27.08$)$ and in the skin of adult leaves (LSD ${ }_{0.05}$ test \pm 22.61). At the later stage, no differences were found. Similarly, Jureková et al. (2012) reported dependence of a number of stomata in the skin of juvenile leaves on genotypes of $M$. sinensis 'Tatai' from the same site in 2012. Fraser et al. (2009) found out that stomatal density of Pseudoroegneria spicata is not a phenotypically plastic plant trait but it is also genotypically differentiated.

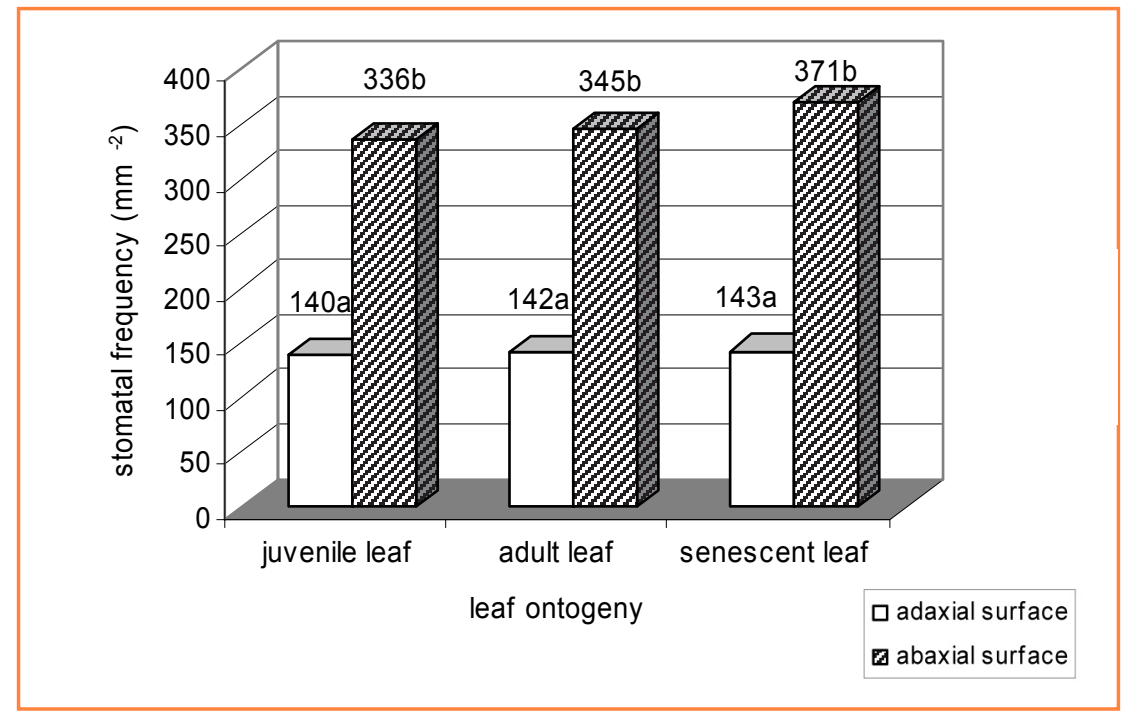

Figure 1 Statistical evaluation of significant differences in the number of stomata per $\mathrm{mm}^{-2}$ of the adaxial and abaxial surface depending on the leaf ontogeny of $M . \times$ giganteus. Values with different letters $(a, b)$ in columns indicate statistically significant difference according to the LSD test $(P<0.05)$

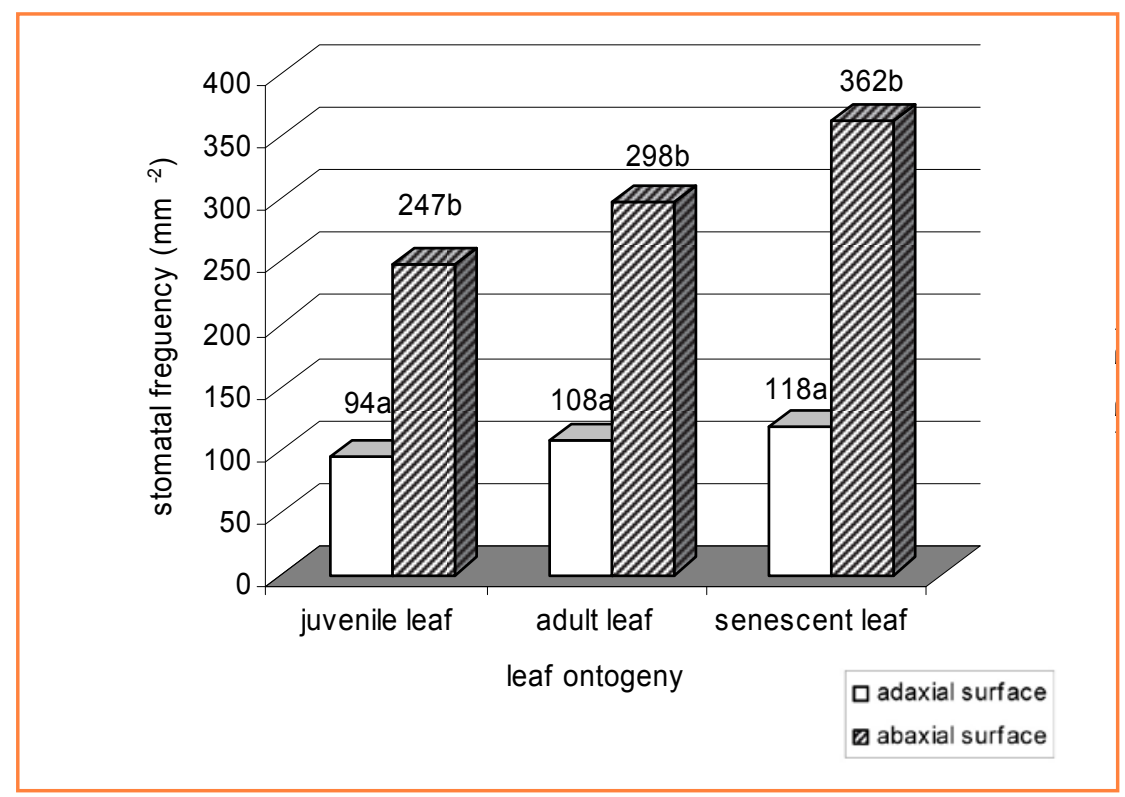

Figure 2 Statistical evaluation of significant differences in the number of stomata per $\mathrm{mm}^{-2}$ of the adaxial and abaxial surface depending on the leaf ontogeny of $M$. sinensis 'Tatai'. Values with different letters $(a, b)$ in columns indicate statistically significant difference according to the LSD test $(P<0.05)$

Table 1 Changes of the leaf area size in $\mathrm{m}^{-2}$ of the studied genotypes according to localization regarding to cardinal directions

\begin{tabular}{|l||c|c|c|c|}
\hline \multirow{2}{*}{ Phase of leaf growth } & Leaf area in $\mathbf{~ m}^{-2}-$ Miscanthus $\times$ giganteus & \multicolumn{2}{|c|}{ Leaf area in $\mathbf{~ m}^{-2}-$ Miscanthus sinensis ' ${ }^{\text {'Tatai' }}$} \\
\cline { 2 - 4 } & north & east & 0.14534 & 0.13052 \\
\hline Juvenile leaf & 0.11375 & 0.09469 & 0.13406 & 0.14872 \\
\hline Adult leaf & 0.12187 & 0.14632 & 0.12268 & 0.12667 \\
\hline Beginning of senescence & 0.09828 & 0.14632 & 0.11154 & 0.12667 \\
\hline Senescence leaf & 0.09201 & 0.10790 & & \\
\hline
\end{tabular}




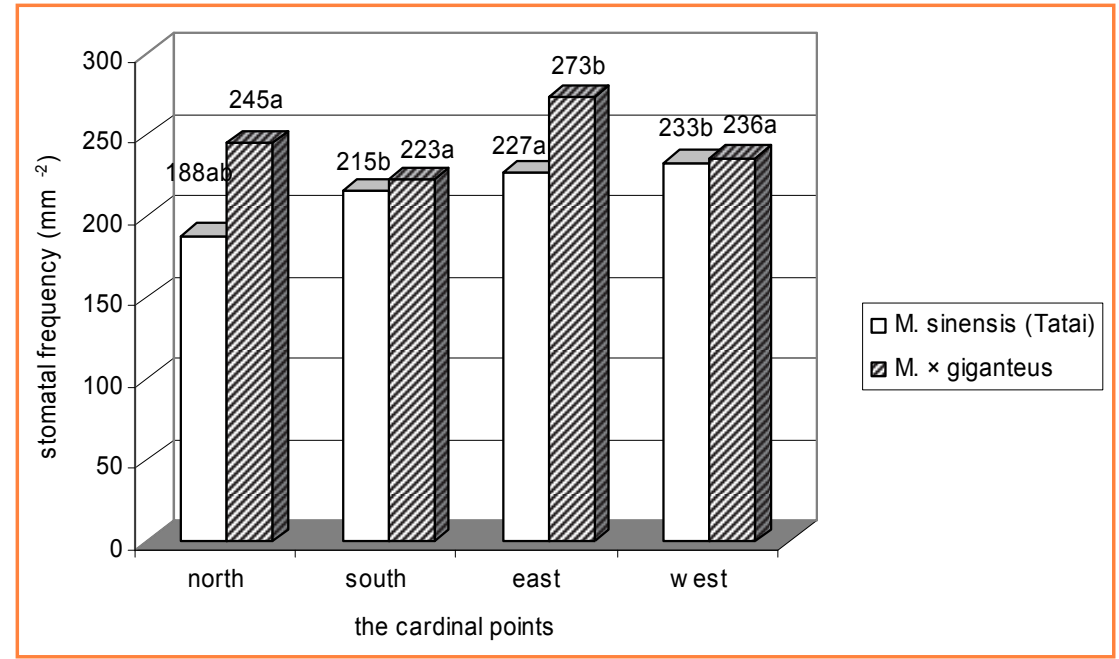

Figure 3 Statistical evaluation of significant differences in the number of stomata per $\mathrm{mm}^{-2}$ of the senescent leaves Miscanthus depending on the cardinal directions. Values with different letters $(a, b)$ in columns indicate statistically significant difference according to LSD test $(P<0.05)$

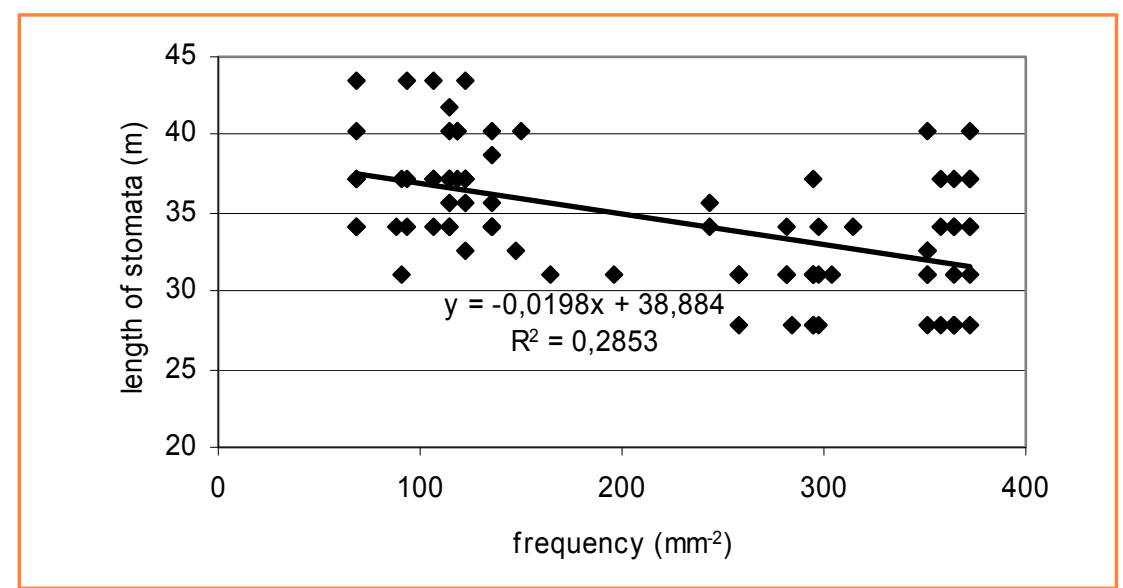

Figure 4 Linear dependence between the number of stomata per $\mathrm{mm}^{-2}$ and the stomatal length in $\mu \mathrm{m}$

The number of stomata in leaves was statistically highly significantly affected by adaxial and abaxial leaf surface of the skin in all three stages of ontogeny of $M . \times$ giganteus $\left(\mathrm{LSD}_{0.05}\right.$ test $\left.\pm 54.54, \pm 29.02, \pm 43.79\right)$ (Figure 1) and M. sinensis ,'Tatai' $\left(\right.$ LSD $_{0.05}$ test $\left.\pm 38.89, \pm 49.11, \pm 32.90\right)$ (Figure 2). Ratio of stomata was 27:73 on adaxial and abaxial leaf surface, respectively.

The increase in the number of stomata in leaves during the ontogeny was also influenced by climatic factors in the studied year. The average precipitation during the observed months of May, June and July decreased significantly (78, 47 and $2 \mathrm{~mm}$ ) and the average air temperature raised (15.6, 19.3 and $22.8^{\circ} \mathrm{C}$ ) (SHMÚ, 2013). between south and east orientation and west and east orientation were found in $M . \times$ giganteus and were highly significant (LSD 0.05 test 26.82 \pm south and east, LSD 0.05 test \pm 35.72 east and west) (Figure 3). Between north, south and west each other there are no significant differences in the density of stomata. In the second observed genotype $M$. sinensis 'Tatai', the dependence of stomata from the cardinal directions was reflected only in senile leaves. The differences in stomatal density between south and east, south and west were highly significant (LSD 0.05 test \pm 20.15 south and east, LSD 0.05 test \pm 20.15 south and west) (Figure 3 ).

The number of stomata per $\mathrm{mm}^{-2}$ of area varied from $125 \pm 23$ to $327 \pm$ 47 , stomatal length ranged from $33.9 \pm$ $4.7 \mu \mathrm{m}$ to $35.3 \pm 3.4 \mu \mathrm{m}$, and stomatal width from $17.5 \pm 2.3 \mu \mathrm{m}$ to $18.8 \pm$ $2.8 \mu \mathrm{m}$ among the two genotypes. Correlations between the number of stomata per unit area and stomatal width $(r=0.49)$, and between the stomatal length and width $(r=0.35)$ were statistically significant. The values of the correlation coefficient between the number of stomata per unit area and the stomatal length $(r=0.54)$ were evaluated as highly significant (Figure 4). Rayburn et al. (2009) compared the size of stomata of two Miscanthus genotypes in the USA and confirmed genotypic conditionality of the monitored indicator expressed by higher average length of stomata of $M . \times$ giganteus (24.4 $\mu \mathrm{m})$ compared to $M$. sinensis 'Tatai' $(21.8 \mu \mathrm{m})$. These data correspond to our observations where the average length of stomata of $M$. $\times$ giganteus was higher (35.3 $\mu \mathrm{m})$ compared to $M$. sinensis 'Tatai' $(33.9 \mu \mathrm{m})$. However, the width of stomata was higher in $M$. sinensis 'Tatai' $(18.8 \mu \mathrm{m})$ than in $M . \times$ giganteus $(17.5$ $\mu \mathrm{m}$ ). On the contrary (Moon et al., 2013) recorded in the soil and climatic conditions of Korea the average length of stomata of $M . \times$ giganteus shorter $(21 \mu \mathrm{m})$ than that of $M$. sinensis 'Tatai' (22.5 $\mu \mathrm{m})$.

\section{Conclusions}

The results of the experiments with perennial rhizomatous energy grass Miscanthus $\times$ giganteus Greef et Deu and $M$. sinensis 'Tatai' grown in conditions of the South Western Slovakia provide following conclusions 
about stomatal density. The number of stomata per $\mathrm{mm}^{2}$ of area varied from $125 \pm 23$ to $327 \pm 47$, stomatal length ranged from $33.9 \pm 4.7 \mu \mathrm{m}$ to $35.3 \pm 3.4 \mu \mathrm{m}$, and stomatal width from $17.5 \pm 2.3 \mu \mathrm{m}$ to $18.8 \pm 2.8 \mu \mathrm{m}$ in the two genotypes. Stomatal density of adult leaves facing to east was highly significantly greater compared to leaves facing the other cardinal directions. The differences in stomatal density of leaves facing to south and east, to south and west and to east and west in senescent leaves were highly significant. Correlations between the number of stomata per unit area and stomatal width $(r=0.49)$ and between the stomatal length and with $(r=0.35)$ were evaluated as significant. The value of the correlation coefficient between the number of stomata per unit area and the stomatal length $(r=0.54)$ was evaluated as significant.

\section{Acknowledgment}

This paper was supported by project "Build the research centre AgroBioTech" ITMS code 26220220180.

\section{References}

CLIFTON-BROWN, J.C. - LEWANDOWSKI, I. 2000. Water use efficiency and biomass partitioning of three different Miscanthus genotypes with limited and unlimited water supply. In Annals of Botany, vol. 86, 2000, pp. 191-200.

FRASER, L. H. - GREENALL, A. - CARLYLE, C. - TURKINGTON, R. - FRIEDMAN, C. R. 2009. Adaptive phenotypic plasticity of Pseudoroegneria spicata: response of stomatal density, leaf area and biomass to changes in water supply and increased temperature. In Annals of Botany, vol. 103, 2009, no. 5, pp. 769-775.

GREEF, J. M. - DEUTER, M. 1993. Syntaxonomy of Miscanthus $\times$ giganteus GREEF et DEU. In Angewandte Botanik, vol. 67, 1993, pp. 87-90.

JUREKOVÁ, Z. - KOTRLA, M. - PAUKOVÁ, Ž. 2013. Life cycle of Miscanthus $\times$ giganteus Greef et Deu grown in South-Western Slovakia conditions. In Acta Regionalia et Environmentalica, vol. 10, 2013, no. 2, pp. 40-43. DOI: 10.2478/aree-2013-0008.
JUREKOVÁ, Z. - KOTRLA, M. - PAUKOVÁ, Ž. - PRČÍK, M. 2012. The growth and yield of different Miscanthus genotypes in the conditions of South-Western Slovakia. In Acta Regionalia et Environmentalica, vol. 2, 2012, pp. 29-34.

SHMÚ. 2013. Slovak Hydro-meteorological Institute. Data from the meteorological station in the village Vel'ké Janíkovce in 2013. In Department of biometeorology and hydrology, Nitra : Nitra, 2013.

MOON, Y.H. - CHA, Y.L. - CHOI, Y.H. - YOON, Y.M. - KOO, B.CH. et al. 2013. Diversity in ploidy levels and nuclear DNA amounts in Korean Miscanthus species. In Euphytica, vol. 193, 2013, pp. 317-326.

PAZOUREK, J. 1963. Study of leaf epidermis by microrelief method. In Preslia, vol. 35, 1963, pp. 210-216.

PRČÍK, M. - KOTRLA, M. 2013. Evaluation of dry matter production of Miscanthus sinensis 'Tatai' in the condition of South-Western Slovakia. In Acta Regionalia et Environmetalica, vol. 10, 2013, no. 2, pp. 55-58. DOI: 10.2478/aree-2013-0012.

RICHARDSON, A.D. - ASHTON, P.M.S. - BERLYN,G.P - MC GRODY, M.E. - CAMERON, I.R. 2001. Within-crown foliar plasticity of western hemlock, Tsuga heterophylla in relation to stand age. In Annals of Botany, vol. 88, 2001, pp. 1007-1015.

RAYBURN, A.L. - Crawford, J. - RAYBURN, CH.M. - JUVIK, J.A. 2009. Genome size of three Miscanthus species. In Plant Molecular Biology Reporter, Springer Science, Business Media B.V., vol. 27, 2009, pp. 184-188.

THOMAS, P.W. - WOODWARD, F.I. - QUICK, W.P. 2003. Systemic irradiance signaling in tobacco. In New Phytologist, vol. 161, 2003, pp. 193-198.

VOLKENBURGH, E.V. 1999. Leaf expansion - an integrating plant behavior. In Plant, Cell and Environment, vol. 22, 1999, pp. 14631473. DOI: 10.1046/j.1365-3040.1999.00514.x

WANG, Y. - CHEN, X. - XIANG, C. 2007. Stomatal density and biowater saving. In Journal of Integrative Plant Biology, vol. 49, 2007, pp. $1435-1444$.

WOODWARD, F.I. - KELLY, C.K. 1995. The influence of $\mathrm{CO}_{2}$ concentration on stomatal density. In New Phytologist, vol. 131, 1995, pp. 311-327.

XU, Z. - ZHOU, G. 2008. Responses of leaf stomatal density to water status and its relationship with photosynthesis in a grass. In Journal of Experimental Botany, vol. 59, 2008, pp. 3317-3325. 